\title{
Article \\ Utilization of Wool Integral Lipids to Determine Milk Fat Content in Suffolk Down Ewes
}

\author{
Karla Inostroza $^{1, * \mathbb{D}}$, Giovanni Larama ${ }^{2} \mathbb{D}$, Silvana Bravo $^{3}$, Mario Díaz $^{4}$ and Néstor Sepúlveda ${ }^{1}$ \\ 1 Centro de Tecnología e Innovación de la Carne, Facultad de Ciencias Agropecuarias y Forestales, Center of \\ Biotechnology on Reproduction, Scientific and Technological Bioresource Nucleus Universidad de La \\ Frontera, P.O. Box 54-D, Temuco 4780000, Chile; nestor.sepulveda@ufrontera.cl \\ 2 Agriaquaculture Nutritional Genomic Center, CGNA, Temuco 4780000, Chile; giovanni.larama@cgna.cl \\ 3 Instituto de Producción Animal, Facultad de Ciencias Agrarias y Alimentarias, Universidad Austral de Chile, \\ P.O. Box 567, Valdivia 5090000, Chile; silvana.bravo@uach.cl \\ 4 Programa de Magister en Ciencias Mención Genética, Escuela de Graduados, Facultad de Ciencias, \\ Universidad Austral de Chile, Valdivia 5090000, Chile; mariodiazmatus@gmail.com \\ * Correspondence: karla.inostroza@ufrontera.cl
}

check for updates

Citation: Inostroza, K.; Larama, G.; Bravo, S.; Díaz, M.; Sepúlveda, N.

Utilization of Wool Integral Lipids to Determine Milk Fat Content in

Suffolk Down Ewes. Appl. Sci. 2022, 12, 1046. https://doi.org/10.3390/ app12031046

Academic Editor: Massimo Lucarin

Received: 9 December 2021

Accepted: 19 January 2022

Published: 20 January 2022

Publisher's Note: MDPI stays neutral with regard to jurisdictional claims in published maps and institutional affiliations.

Copyright: (c) 2022 by the authors. Licensee MDPI, Basel, Switzerland. This article is an open access article distributed under the terms and conditions of the Creative Commons Attribution (CC BY) license (https:// creativecommons.org/licenses/by/ $4.0 /)$.

\begin{abstract}
The identification of higher fat content in ewe milk during lactation can help to improve the nutritional value and quality of the derived dairy products. In this study, we characterized fatty acids from the wool of Suffolk ewes at two time points during lactation and assessed whether they were related to milk fat content through discriminant analysis and, thus, could be potentially used to identify ewes with a high fat content. Eighty single-bearing Suffolk ewes of similar body weight, body score, and age were selected for this study. The overall fat contents of milk and wool were determined, as well as the fatty acids in the wool. The wool fat content was $1.14 \%$ on average. The proportions of wool fatty acids were $65.82 \%$ saturated, $21.70 \%$ monounsaturated, and $12.48 \%$ polyunsaturated fatty acids. The wool fatty acid concentrations of C18:1n9c, C18:2n6c, and C22:2 were higher in ewes whose milk had a high fat content at both time points. Moreover, the levels of these fatty acids were positively correlated with milk fat content. Discriminant analyses using C18:1n9c and C18:2n6c were the best candidates for the prediction of high milk fat content, with an accuracy of $87.50 \%$. The wool fatty acids C18:1n9c and C18:2n6c could potentially be used to determine the milk fat content of ewes.
\end{abstract}

Keywords: wool; fatty acids; milk fat

\section{Introduction}

Sheep farming is of vital importance to national economies, principally in the Mediterranean basin, particularly in France, Spain, Italy, and Greece [1]. In the Mediterranean and East European countries sheep milk is often produced by specialized dairy breeds, and sheep milk products are commercialized internationally. Consequently, due to the high quality of sheep milk products, more consumers are demanding dairy products with a special flavor associated with the territory where the animals live [2]. On the other hand, in South America, sheep milk production is traditionally performed by hand, and the raw milk is used directly, without the addition of dairy cultures, which gives these products their typical flavors and aromas [3]. In fact, an increase in cheese varieties from manufacturers using sheep milk has been observed in Chile; however, the production system varies according to the country; e.g., in Chile, sheep production is based largely on grazing systems, whereas in Spain, for example, sheep cheese is produced throughout the year, leading to intensification and the need for reproductive management [4]. This significant growth in sheep cheese production has stimulated research into sheep milk production with various breeds and production systems [5,6].

Dairy milk products from sheep have acquired importance in the global market, due to their nutritional value and high quality [1]. The nutritional value of sheep milk is 
characterized by higher levels of total solids and major nutrients, compared with milk from other mammals; with lipids being the most important components of milk, in terms of cost, nutrition, and the physical and sensory characteristics that they impart to dairy products [7]. Most sheep milk produced throughout the world is transformed into cheese. Rarely is sheep milk directly consumed and, thus, the majority of efforts are focused on its transformation into high quality dairy products [8]. The nutritional value of products depends on the type of milk from which they are made, and in sheep cheese, the fat content is important, because fat defines the consistency, taste, aroma, and nutritional value of the resulting dairy product [9]. The fat concentration in milk can be altered by diet, and particularly by factors that affect rumen fermentation [2]. Thus, the nutritional value and sensory properties of milk are of great importance, and the determination of fat content during lactation is relevant in the manufacturing of dairy products [10].

Wool is important as a textile fiber and is increasing in popularity, despite the current restrictions on the use of agricultural by-products that classify wool as a waste product, with no economic incentives to valorize wool beyond disposal [11]. Wool, similarly to hair, is a metabolically inert and incremental tissue and can, thus, provide an archival record, e.g., of changes in diet, with the advantage that it can be noninvasively, collected and conveniently stored with little cost for long periods of time; thus, preserving this information for retrospective verification [12]. Moreover, researchers have found that it is possible to detect drug residues in hair long after treatment [13]. Hair has become an important focus in diverse fields of animal research, due to the information it can provide about an animals' environment [12,13], and it reflects the metabolism of the proceeding 2 to 3 weeks [14]. Previous studies have established a relationship between the fatty acid profile of hair and energy availability in lactating cows, reproduction, and milk protein [14,15]. However, no information exists about sheep wool fatty acids and their relationship with milk productive parameters. According to the present knowledge about hair, we expected that information about the chemical composition of sheep milk, specifically milk fat content, could be reflected in wool fatty acids. Thus, the aim of this study was to differentiate sheep's milk with high fat content at two time points during lactation (30 and 60 days) using wool fatty acids. Such a differentiation could prove a helpful tool for optimizing the features of sheep's milk and dairy products with high nutritional value and characteristic sensory properties.

\section{Materials and Methods}

\subsection{Animals and Production System}

Eighty healthy single-bearing Suffolk Down ewes were selected after lambing, with an initial body weight of $68.2 \pm 5.4 \mathrm{~kg}$; a body condition score of $2.7 \pm 0.4$ estimated on a scale of five points, from 1 (thin) to 5 (obese) [16]; and aged $3.3 \pm 0.5$ years. They were selected from the flock at a farm located in the Araucanía region $\left(38^{\circ} 54^{\prime} \mathrm{S}, 72^{\circ} 40^{\prime} \mathrm{W}\right)$. According to the Chilean Meteorological Directorate, meteorological data from the local station indicated that the annual average temperature was $11.3^{\circ} \mathrm{C}$, with a maximum and minimum of $26.2{ }^{\circ} \mathrm{C}$ in February and $2.9^{\circ} \mathrm{C}$ in May, respectively. The annual rainfall was $975.6 \mathrm{~mm}$, and $49.9 \%$ of the precipitation was concentrated in June and July. This study was carried out during lambing (June), to select single-bearing ewes, and sampling was conducted in July and August (corresponding to 30 and 60 days in milk). The diet of the ewes was based on natural pasture and was supplemented in the morning with oats during the first month of lactation (100 g/head/day). Pasture samples were collected at 30 and 60 days in milk from three areas $\left(0.5 \mathrm{~m}^{2}\right.$ each). These were weighed and air-oven dried at $65^{\circ} \mathrm{C}$ for $48 \mathrm{~h}$ for the determination of dry matter (DM) [17]. The pasture and oat fatty acid compositions were determined using the miniaturized Bligh-Dyer method [18] and according to Folch et al. [19], respectively. The stocking rate was set to 12 sheep ha ${ }^{-1}$. Fresh water was available ad libitum. The Suffolk Down ewes were maintained under the same management conditions during the trial. The milk and wool samples were obtained according to the routine management of the ewes, with no changes in feed or administration 
of medication. This study was approved by the University of La Frontera Scientific Ethical Committee (ethical review number 101_17).

\subsection{Milk Samples and Analysis}

The milk samples were collected at 30 and 60 days in milk. All ewes were first milked to remove residual milk and separated from lambs for a period of $8 \mathrm{~h}$, to provide the appropriate period for milk secretion [20]. The ewes were hand milked, and a $50 \mathrm{~mL}$ sample was taken from each ewe for analysis and refrigerated at $4{ }^{\circ} \mathrm{C}$ to determine milk fat. The milk fat was determined using Fourier infrared analysis with a MilkoScan 4000 (FOSS, Hillerod, Denmark), according to standard ISO 9622:2013 IDF 141 [21]. The ewes were classified according to milk fat content into two groups: ewes with a high or low milk fat content at a threshold of $\geq$ or $<7 \%$, respectively. This threshold was determined in accordance with the values of all analyzed ewes and the milk fat values reported by the literature $[1,7]$.

\subsection{Wool Analysis}

Wool samples from Suffolk Down ewes were collected from the superior left-side hind leg at 30 and 60 days in milk. The wool was cut near the skin and stored in individually labeled paper bags at $-20^{\circ} \mathrm{C}$ until analysis. Prior to internal-lipid extraction, it is important to remove the surface lipids and contaminants, especially from wool; thus, the wool was cleaned by rinsing with dichloromethane, evaporated under nitrogen gas, and dried at $35^{\circ} \mathrm{C}$ for $5 \mathrm{~h}[14,22]$. A total of $1 \mathrm{~g}$ of clean wool was excised and ground in a mortar with liquid nitrogen. The wool fatty acids were extracted using a modified Folch method [19]. Briefly, total lipids from ground wool were extracted with $20 \mathrm{~mL}$ hexane/isopropanol $(2: 1 \mathrm{v} / \mathrm{v})$. The samples were magnetically shaken and filtered. Lipids were retained in the hexane layer. After concentrating and evaporating the solvent with nitrogen gas, the extracted lipids were weighed to determine wool fat content [14]. For the formation of fatty acids methyl esters (FAMEs), $1.3 \mathrm{~mL}$ potassium hydroxide in $2 \mathrm{~N}$ methanol, and $0.8 \mathrm{~mL}$ n-hexane were added for lipid extraction, followed by shaking for $30 \mathrm{~min}$. The supernatant was filtered with anhydrous sodium sulfate and transferred into a vial for direct injection of $1 \mu \mathrm{L}$ into a gas chromatography model Clarus 500 (Perkin Elmer, Buckinghamshire, UK) equipped with a flame ionization detector (FID), autosampler, split injection, and a fused silica capillary column SPTM $2380(60 \mathrm{~m} \times 0.25 \mathrm{~mm} \times 0.2 \mu \mathrm{m}$ film thickness) (Supelco, Bellefonte, PA, USA). The following chromatograph temperature conditions were applied: The initial oven temperature was $150^{\circ} \mathrm{C}$ (held for $1 \mathrm{~min}$ ). This was subsequently increased to $168{ }^{\circ} \mathrm{C}$, at a rate of $1{ }^{\circ} \mathrm{C} \mathrm{min}^{-1}$ (held for $11 \mathrm{~min}$ ), and to $230^{\circ} \mathrm{C}$ at $6^{\circ} \mathrm{C} \mathrm{min}-1$ (held for $8 \mathrm{~min}$ ). The temperature of the injector and FID was $250^{\circ} \mathrm{C}$, and nitrogen was used as the carrier gas, at a flow rate of $1 \mathrm{~mL} \mathrm{~min}^{-1}$. Finally, FAMEs were individually identified by comparison with the standard FAME Mix C4-C24 (Supelco, Pennsylvania, PA, USA), which contains 37 FAMEs, and analyzed under the same conditions. For the quantification of wool FAs, we used the internal standard nonadecanoic acid analytical standard (C19:0; Merck Darmstadt, Germany), which was added to each sample and the standard mixture.

\subsection{Statistical Analysis}

Significant differences in FAs, ratios, wool fat concentration, and milk fat content between the groups of high and low milk fat contents, at 30 and 60 days in milk, were determined using $t$-testing. Pearson's correlation coefficients were determined to evaluate the relationship between the wool FA composition and milk fat content at 30 and 60 days in milk. All statistical analyses were performed in SPSS Statistical Software (IBM SPSS Statistics for Windows, Version 23.0. Armonk, NY, USA: IBM Corp.), and $p<0.05$ was considered significant. The wool FAs and wool fat contents were subjected to discriminant analysis. This analysis was used to identify the most discriminating wool FAs and wool fat contents for classification, based on milk fat content. The classification procedure was performed using a linear discriminant function, a total of six models were built, using the 
combination of these variables, and their performance was evaluated by cross-validation. All these functions in addition to the accuracy and Matthews correlation coefficient (MCC) were calculated in the statsmodels library using the Python programming language, as implemented in [23].

\section{Results}

\subsection{Fatty Acid Composition of Ewes' Diets}

The diet of the ewes was based on pasture, supplemented with oats. The DM of the natural pasture at 30 and 60 days in milk was 410 and $650 \mathrm{~kg} \mathrm{DM}^{-1}$, respectively. The fatty acid compositions of the pasture and oat samples are presented in Table 1 . The main FAs identified in the pastures were C18:3n3, C18:2n6c, and C16:0. The most common forage species in the natural pasture were perennial ryegrass (Lolium perenne), annual bluegrass (Poa annua L.), hairy cat's ear (Hypochaeris radicata), white clover (Trifolium repens L.), and common yarrow (Achillea millefolium L.).

Table 1. Fatty acid composition of pasture and oat.

\begin{tabular}{cccc}
\hline \multirow{2}{*}{$\begin{array}{c}\text { Fatty Acid } \\
\text { (mg/g DM) }\end{array}$} & \multicolumn{2}{c}{ Pasture } & Oat \\
\cline { 2 - 4 } & 30 Days in Milk & 60 Days in Milk & 8.46 \\
\hline C16:0 & 0.23 & 0.10 & 1.57 \\
C18:0 & 0.08 & 0.03 & 25.75 \\
C18:1n9c & 0.03 & 0.02 & 23.56 \\
C18:2n6c & 0.23 & 0.07 & 0.24 \\
C18:3n3 & 1.33 & 0.44 & \\
\hline
\end{tabular}

\subsection{Wool Fat and Fatty Acid Composition}

There was no difference in wool fat content between groups with low or high milk fat contents at either 30 or 60 days. The fat content of wool was $1.14 \%$ on average. The principal component of wool FAs was saturated fatty acid (SFA), which contributed $65.82 \pm 1.84 \%$ of FAMEs. With the lowest proportions, monounsaturated (MUFA) and polyunsaturated (PUFA) fatty acids represented $21.70 \pm 1.09 \%$ and $12.48 \pm 1.24 \%$, respectively, of the total FAMEs. The predominant FAs in the wool samples were $\mathrm{C} 16: 0, \mathrm{C} 18: 0$, and $\mathrm{C} 18: 1 \mathrm{n} 9 \mathrm{c}$, which together represented $57.42 \%$ of total FAMEs. C16:0 followed by C18:0 were the main FAs in the SFA fraction. These FAs represented $28.87 \pm 0.94 \%$ and $17.17 \pm 0.65 \%$ of the total SFA in wool FAs, respectively. C18:1N9c (11.38 $\pm 1.19 \%)$ and C14:1 (5.56 $\pm 0.39 \%)$ were the MUFAs with the highest contents. C22:6n3 and C18:2n6c were the FAs found at the highest proportions in the PUFA fraction $(5.63 \pm 0.51 \%$ and $4.78 \pm 0.54 \%$, respectively).

The groups were classified according to milk fat content variables (Table 2), as high and low fat content over two lactation periods (30 and 60 days). Both groups differed significantly in the milk fat variable $(p<0.05)$. For each time point classification (30 and 60 days), several FAs were significantly different between groups for milk fat content $(p<0.05)$. The FAs C18:1n9c, C18:2n6c, and C22:2 exhibited a higher concentration of wool FAs in both classifications (30 and 60 days) when milk had a high fat content. In particular, in the first period of 30 days in milk, ewe milk with a high fat content had high levels of the FAs C14:0 and C20:3n6, and lower concentrations of C14:1 and C15:0 in wool. By contrast, the milk collected at 60 days showed significant changes in the concentration of ten FAs, including the FAs C16:0, C18:0, and C24:1n9. The concentrations of the FAs C10:0, C13:0, C14:1, C16:0, C16:1, C18:0, and C24:1n9 increased in this period in wool when the ewe milk had a high fat content $(p<0.05)$. 
Table 2. Wool fatty acid (FA) composition ( $\mu \mathrm{g} / \mathrm{g}$ of wool) and milk fat content (\%) of Suffolk Down ewes $(n=80)$.

\begin{tabular}{|c|c|c|c|c|c|c|c|}
\hline \multirow[b]{2}{*}{ Fatty Acids } & & \multicolumn{3}{|c|}{30 Days in Milk } & \multicolumn{3}{|c|}{60 Days in Milk } \\
\hline & & $\begin{array}{c}\text { Low }^{1} \\
(n=40)\end{array}$ & $\begin{array}{l}\text { High }^{2} \\
(n=40)\end{array}$ & $p$-Value & $\begin{array}{c}\text { Low }^{1} \\
(n=40)\end{array}$ & $\begin{array}{l}\text { High }^{2} \\
(n=40)\end{array}$ & $p$-Value \\
\hline Capric acid & $\mathrm{C} 10: 0$ & $1.51 \pm 0.28$ & $1.45 \pm 0.64$ & 0.600 & $1.11 \pm 0.33^{b}$ & $1.59 \pm 0.39^{\mathrm{a}}$ & 0.000 \\
\hline Lauric acid & $\mathrm{C} 12: 0$ & $2.40 \pm 0.23$ & $2.25 \pm 0.45$ & 0.064 & $2.02 \pm 0.42$ & $2.19 \pm 0.38$ & 0.053 \\
\hline Tridecanoic acid & C13:0 & $0.81 \pm 0.19$ & $0.79 \pm 0.32$ & 0.727 & $0.52 \pm 0.17^{\mathrm{b}}$ & $0.85 \pm 0.31^{\mathrm{a}}$ & 0.001 \\
\hline Myristic acid & C14:0 & $9.26 \pm 1.94^{b}$ & $15.56 \pm 5.13^{\mathrm{a}}$ & 0.000 & $13.42 \pm 4.09$ & $13.76 \pm 3.37$ & 0.685 \\
\hline Myristoleic acid & C14:1 & $25.77 \pm 3.65^{\mathrm{a}}$ & $18.95 \pm 3.28^{b}$ & 0.000 & $17.67 \pm 3.35^{b}$ & $23.75 \pm 7.28^{a}$ & 0.000 \\
\hline Pentadecanoic acid & C15:0 & $5.58 \pm 0.81^{\mathrm{a}}$ & $5.03 \pm 1.04^{b}$ & 0.010 & $4.91 \pm 1.35$ & $5.49 \pm 1.43$ & 0.067 \\
\hline Palmitic acid & $\mathrm{C} 16: 0$ & $112.61 \pm 10.95$ & $108.25 \pm 24.51$ & 0.309 & $88.23 \pm 10.61^{b}$ & $124.20 \pm 22.94^{\mathrm{a}}$ & 0.000 \\
\hline Palmitoleic acid & $\mathrm{C} 16: 1$ & $2.76 \pm 0.62$ & $2.29 \pm 1.04$ & 0.059 & $1.40 \pm 0.51^{\mathrm{b}}$ & $2.12 \pm 0.70^{\mathrm{a}}$ & 0.003 \\
\hline Heptadecanoic acid & C17:0 & $13.95 \pm 3.44$ & $11.61 \pm 4.87$ & 0.059 & $13.24 \pm 6.26$ & $14.11 \pm 6.75$ & 0.608 \\
\hline Stearic acid & C18:0 & $65.02 \pm 6.67$ & $62.39 \pm 15.00$ & 0.316 & $50.35 \pm 4.09^{b}$ & $73.69 \pm 13.03^{a}$ & 0.000 \\
\hline Oleic acid & $\mathrm{C} 18: \ln 9 \mathrm{c}$ & $15.19 \pm 4.26^{b}$ & $28.44 \pm 7.25^{\mathrm{a}}$ & 0.002 & $15.58 \pm 4.01 \mathrm{~b}$ & $27.36 \pm 8.65^{\mathrm{a}}$ & 0.001 \\
\hline Linoleic acid & $\mathrm{C} 18: 2 \mathrm{n} 6 \mathrm{c}$ & $15.47 \pm 2.46^{\mathrm{b}}$ & $21.23 \pm 6.11^{\mathrm{a}}$ & 0.000 & $12.44 \pm 3.53^{b}$ & $19.82 \pm 3.70^{\mathrm{a}}$ & 0.000 \\
\hline Arachidic acid & C20:0 & $1.60 \pm 0.36$ & $1.84 \pm 0.70$ & 0.056 & $1.79 \pm 0.71$ & $2.05 \pm 0.62$ & 0.086 \\
\hline$\alpha$-Linolenic acid & C18:3n3 & $6.66 \pm 1.16$ & $6.35 \pm 2.52$ & 0.481 & $6.48 \pm 1.15^{b}$ & $8.21 \pm 2.86^{\mathrm{a}}$ & 0.001 \\
\hline Behenic acid & C22:0 & $4.93 \pm 1.37$ & $4.79 \pm 1.71$ & 0.698 & $5.22 \pm 1.62$ & $5.20 \pm 1.74$ & 0.954 \\
\hline cis-8,11,14-Eicosatrienoic acid & C20:3n6 & $3.38 \pm 0.85^{b}$ & $6.60 \pm 2.36^{a}$ & 0.000 & $6.23 \pm 2.09$ & $5.17 \pm 2.12$ & 0.077 \\
\hline cis-13,16-Docosadienoic acid & $\mathrm{C} 22: 2$ & $8.33 \pm 1.57^{b}$ & $13.39 \pm 5.11^{\mathrm{a}}$ & 0.004 & $7.47 \pm 3.22^{b}$ & $10.38 \pm 3.31^{\mathrm{a}}$ & 0.000 \\
\hline Lignoceric acid & $\mathrm{C} 24: 0$ & $12.75 \pm 2.45^{b}$ & $15.42 \pm 4.68^{\mathrm{a}}$ & 0.002 & $14.41 \pm 3.97$ & $16.58 \pm 6.42$ & 0.074 \\
\hline Nervonic acid & C24:1n9 & $30.70 \pm 6.03$ & $29.80 \pm 11.32$ & 0.062 & $21.44 \pm 8.44^{b}$ & $31.74 \pm 11.76^{\mathrm{a}}$ & 0.000 \\
\hline Docosahexaenoic acid & $\mathrm{C} 22: 6 \mathrm{n} 3$ & $18.23 \pm 3.43$ & $21.36 \pm 8.21$ & 0.058 & $17.40 \pm 3.54$ & $22.14 \pm 8.75$ & 0.054 \\
\hline \multicolumn{8}{|l|}{ Proportions FA } \\
\hline SFA $^{3}$ & & $230.40 \pm 16.79$ & $229.39 \pm 29.70$ & 0.852 & $195.23 \pm 18.13^{b}$ & $259.72 \pm 36.46^{\mathrm{a}}$ & 0.000 \\
\hline MUFA 4 & & $74.67 \pm 7.83$ & $79.49 \pm 13.15$ & 0.051 & $56.09 \pm 12.07^{b}$ & $84.97 \pm 18.96^{\mathrm{a}}$ & 0.000 \\
\hline PUFA $^{5}$ & & $52.46 \pm 5.08^{\mathrm{b}}$ & $68.93 \pm 14.79^{a}$ & 0.000 & $50.04 \pm 8.65^{\mathrm{b}}$ & $65.73 \pm 15.76^{\mathrm{a}}$ & 0.006 \\
\hline \multicolumn{8}{|l|}{ Desaturase index } \\
\hline DI C14 6 & & $0.73 \pm 0.05^{\mathrm{a}}$ & $0.55 \pm 0.01^{b}$ & 0.000 & $0.57 \pm 0.09$ & $0.61 \pm 0.09$ & 0.058 \\
\hline $\mathrm{DIC} 16^{7}$ & & $0.02 \pm 0.01$ & $0.02 \pm 0.01$ & 0.577 & $0.01 \pm 0.005$ & $0.02 \pm 0.007$ & 0.161 \\
\hline DI C $18^{8}$ & & $0.19 \pm 0.04^{\mathrm{b}}$ & $0.32 \pm 0.07^{\mathrm{a}}$ & 0.000 & $0.24 \pm 0.05$ & $0.26 \pm 0.06$ & 0.067 \\
\hline \multicolumn{8}{|l|}{ Fat content } \\
\hline Wool fat (g/g of wool) & & $0.01 \pm 0.005$ & $0.01 \pm 0.003$ & 0.172 & $0.01 \pm 0.004$ & $0.01 \pm 0.003$ & 0.290 \\
\hline Milk fat (\%) & & $6.43 \pm 0.66^{b}$ & $9.27 \pm 1.00^{\mathrm{a}}$ & 0.000 & $7.16 \pm 0.48^{b}$ & $9.24 \pm 0.87^{\mathrm{a}}$ & 0.000 \\
\hline
\end{tabular}

Data expressed as mean values \pm standard deviation (SD). ${ }^{\mathrm{a}, \mathrm{b}}$. Mean values within a row of the same point of classification (30 or 60 days in milk) with different letters are significantly different $(p<0.05) .{ }^{1}$ Low: low milk fat content $<7 \%$. ${ }^{2}$ High: high milk fat content $\geq 7 \% .{ }^{3}$ SFA: saturated fatty acids, sum of C10:0 + C12:0 + C13:0 + $\mathrm{C} 14: 0+\mathrm{C} 15: 0+\mathrm{C} 16: 0+\mathrm{C} 17: 0+\mathrm{C} 18: 0+\mathrm{C} 20: 0+\mathrm{C} 22: 0+\mathrm{C} 24: 0 .{ }^{4}$ MUFA: monounsaturated fatty acids, sum of $\mathrm{C} 14: 1+\mathrm{C} 16: 1+\mathrm{C} 18: 1 \mathrm{n} 9 \mathrm{c}+\mathrm{C} 24: 1 \mathrm{n} 9 .{ }^{5}$ PUFA: polyunsaturated fatty acids, sum of C18:2n6c + C18:3n3 + C20:3n6 $+\mathrm{C} 22: 2+\mathrm{C} 22: 6 \mathrm{n} 3 .{ }^{6}$ DI C14: desaturase index C14 = C14:1/(C14:0 + C14:1). ${ }^{7}$ DI C16: desaturase index C16 = $\mathrm{C} 16: 1 /(\mathrm{C} 16: 0+\mathrm{C} 16: 1) .{ }^{8} \mathrm{DI} \mathrm{C} 18:$ desaturase index $\mathrm{C} 18=\mathrm{C} 18: 1 \mathrm{n} 9 \mathrm{c} /(\mathrm{C} 18: 0+\mathrm{C} 18: 1 \mathrm{n} 9 \mathrm{c})$.

The FA proportion (SFA, MUFA, and PUFA) and desaturase index (DI) differed significantly between wool collected during the two different time periods ( 30 and 60 days), in terms of the milk fat content variable $(p<0.05)$. For each classification, only the concentration of total PUFA in wool FAs exhibited significant differences between both periods and milk fat content. Ewe milk with a high fat content at 30 and 60 days exhibited a higher PUFA content of wool FAs $(p<0.05)$. No significant differences were observed in the SFA and MUFA fractions at 30 days in milk $(p>0.05)$. However, in the classification of 60 days in milk, the concentration of SFA and MUFA differed significantly in relation to the milk fat content variable. The fraction of the FAs SFA and MUFA exhibited the greatest concentration in wool from ewes with a higher milk fat content. The DI range was $0.55-0.73$ for DI C14, $0.01-0.02$ for DI C16, and $0.19-0.32$ for DI C18. Moreover, the DI only differed significantly between the milk groups collected at 30 days, in comparison to those at 60 days. In the 30-day wool, the DI C14 was higher in the low milk fat content group, whereas the DI C18 was higher in the high milk fat group. No significant differences were found in the DI C16 group $(p>0.05)$.

To determine the relationship between wool FAs and milk fat content, the correlations between each classification period, according to the milk fat variable, were calculated 
(Table 3). For each classification, C18:1n9c, C18:2n6c, and C22:2 were the only FAs that demonstrated a positive correlation between each classification period (30 and 60 days) and milk fat content. Furthermore, in the first period of 30 days in milk, positive correlations were determined in SFAs (C14:0 and C24:0) and PUFA (C20:3n6). For the FA proportions and DI, only the PUFA content and DI C18 exhibited a positive correlation with milk fat content. Moreover, negative correlations were determined for SFA (C15:0 and C18:0), MUFA (C14:1), and DI C14 with milk fat content. In the second period of 60 days, the SFAs (C10:0, C12:0, C13:0, C15:0, and C16:0), MUFAs (C14:1, C16:1, and C24:1n9), and PUFAs (C18:3n3 and C22:6n3) were positively correlated with milk fat content. Moreover, the proportions of all FAs, i.e., SFA, MUFA, and PUFA, and DI C18 were shown to have a positive correlation with milk fat content in this period, with the exception of the FA C20:3n6, which exhibited a negative correlation.

Table 3. Pearson's correlation coefficients among wool fatty acid content and milk fat content.

\begin{tabular}{|c|c|c|}
\hline \multirow{2}{*}{ Fatty Acids } & \multicolumn{2}{|c|}{ Milk Fat Content } \\
\hline & 30 Days in Milk & 60 Days in Milk \\
\hline C10:0 & 0.005 & $0.528 * *$ \\
\hline C12:0 & -0.177 & $0.263 *$ \\
\hline C13:0 & 0.035 & $0.547^{* *}$ \\
\hline C14:0 & $0.570^{* *}$ & 0.012 \\
\hline C14:1 & $-0.527^{* *}$ & $0.374^{* *}$ \\
\hline $\mathrm{C} 15: 0$ & $-0.356^{* *}$ & $0.264 *$ \\
\hline C16:0 & -0.144 & $0.599 * *$ \\
\hline C16:1 & -0.194 & $0.535^{* *}$ \\
\hline C17:0 & -0.157 & -0.027 \\
\hline C18:0 & $-0.246 *$ & $0.646^{* *}$ \\
\hline $\mathrm{C} 18: 1 \mathrm{n} 9 \mathrm{c}$ & $0.699 * *$ & $0.640^{* *}$ \\
\hline $\mathrm{C} 18: 2 \mathrm{n} 6 \mathrm{c}$ & $0.552 * *$ & $0.656^{* *}$ \\
\hline C20:0 & 0.209 & 0.204 \\
\hline C18:3n3 & -0.142 & $0.335^{* *}$ \\
\hline C22:0 & 0.011 & -0.006 \\
\hline C20:3n6 & $0.463^{* *}$ & $-0.258 *$ \\
\hline C22:2 & $0.438^{* *}$ & $0.395^{* *}$ \\
\hline C24:0 & 0.251 * & 0.137 \\
\hline $\mathrm{C} 24: 1 \mathrm{n} 9$ & -0.070 & $0.299 * *$ \\
\hline $\mathrm{C} 22: 6 \mathrm{n} 3$ & 0.196 & $0.229^{* *}$ \\
\hline SFA & -0.120 & $0.628^{* *}$ \\
\hline MUFA & 0.189 & $0.566^{* *}$ \\
\hline PUFA & $0.533^{* *}$ & $0.497^{* *}$ \\
\hline DI C14 & $-0.633^{* *}$ & 0.166 \\
\hline DI C16 & -0.050 & 0.191 \\
\hline DI C18 & $0.698^{* *}$ & 0.271 * \\
\hline Wool fat & -0.150 & 0.149 \\
\hline
\end{tabular}

All FAs were evaluated to perform a discriminant analysis. However, the wool FAs C18:1n9c, C18:2n6c, and C22:2 were the most discriminating variables for the classification of high milk fat content (Table 4). In the validation, the FA C18:1n9c demonstrated an accuracy of $79.17 \%$ as a single factor, which was indicated by the fact that, in the evaluation of 24 ewes, nine ewes were correctly classified as having a high milk fat content, three as false positives, two as false negatives, and 10 as true negatives. The predictions based on the combination of this FA with either $\mathrm{C} 18: 2 \mathrm{n} 6 \mathrm{c}$ or $\mathrm{C} 22: 2$ revealed accuracies of $87.50 \%$ and $70.83 \%$, respectively. However, the combination of all FAs gave an accuracy of $87.50 \%$. Moreover, the MCC exhibited high scores for the combination of C18:1n9c and C18:2n6c $(\mathrm{MCC}=0.75)$, followed by $\mathrm{C} 18: 1 \mathrm{n} 9 \mathrm{c}$ as a single factor with an MCC value of 0.58 . 
Table 4. Discriminant analysis of wool fatty acids and milk fat content, to determine the best classification of ewes with high milk fat content.

\begin{tabular}{lcccccc}
\hline \multicolumn{1}{c}{ Variable } & $\begin{array}{c}\text { True } \\
\text { Positive }\end{array}$ & $\begin{array}{c}\text { False } \\
\text { Positive }\end{array}$ & $\begin{array}{c}\text { False } \\
\text { Negative }\end{array}$ & $\begin{array}{c}\text { True } \\
\text { Negative }\end{array}$ & MCC & Accuracy \\
\hline $\mathrm{C} 18: 1 n 9 c$ & 9 & 3 & 2 & 10 & 0.58 & 79.17 \\
$\mathrm{C} 18: 2 \mathrm{n} 6 \mathrm{c}$ & 8 & 4 & 3 & 9 & 0.41 & 70.83 \\
$\mathrm{C} 22: 2$ & 8 & 5 & 3 & 8 & 0.34 & 66.67 \\
$\mathrm{C} 18: 1 \mathrm{n} 9 \mathrm{c}+\mathrm{C} 18: 2 \mathrm{n} 6 \mathrm{c}$ & 10 & 2 & 1 & 11 & 0.75 & 87.50 \\
$\mathrm{C} 18: 1 \mathrm{n} 9 \mathrm{c}+\mathrm{C} 22: 2$ & 9 & 5 & 2 & 8 & 0.43 & 70.83 \\
$\mathrm{C} 18: 1 \mathrm{n} 9 \mathrm{c}+\mathrm{C} 18: 2 \mathrm{n} 6 \mathrm{c}+\mathrm{C} 22: 2$ & 10 & 2 & 1 & 11 & 0.75 & 87.50 \\
\hline
\end{tabular}

\section{Discussion}

In the present study, wool FAs from Suffolk Down ewes at two time points during lactation (30 and 60 days) were characterized. Wool is a multicomponent fiber consisting of about $97 \%$ proteins, $2 \%$ lipids, and $1 \%$ mineral salts, nucleic acids, and carbohydrates [24]. Internal wool lipids are believed to account for the majority of the lipid content (1.2 to $1.5 \%$ ) [22]. In our study, the wool fat content varied between $1.12 \%$ at 30 days to $1.08-1.25 \%$ at 60 days. Moeller et al. [14] reported that the total fat content of the hair from cows during early lactation ranged between $0.40 \%$ and $1.64 \%$. Thus, the wool fat content reported in this study is similar to that obtained from the hair of cows. In ewes, the wool FAs are mainly composed of SFAs, as in the case of ewe milk samples, with minor proportions of MUFAs and PUFAs [25].

According to the literature [24], the main FAs in wool lipids are C16:0, C18:0, and C18:1n9c, and we identified many of the same FAs in our study. These FAs also were found to be the major FAs in the milk samples and together represented $71.3 \%$ of the total milk FAs [26]. In addition, we detected a small amount of FAs with chain lengths in the range of 12-26 carbon atoms.

Furthermore, other FAs with odd numbers of carbon atoms were found in the wool lipids of Suffolk Down ewes. The FA C15:0 increased in wool FAs at 30 days in milk with low fat content, and no significant differences were detected in the period of 60 days $(p>0.05)$. No significant differences were observed in the C17:0 concentration for each time of classification. Månsson [27] reported that ruminant fat contains certain FAs with an odd number of carbon atoms, such as C15:0 and C17:0, which are synthetized by the bacterial flora in the rumen. According to Jorjong et al. [28], these FAs might provide information concerning the cows' glucose status, as they are synthetized de novo from propionyl-CoA by rumen bacteria or in the mammary gland.

In wool, exogenous dietary essential FAs were also detected, such as $\mathrm{C} 18: 2 \mathrm{n} 6 \mathrm{c}$ and $\mathrm{C} 18: 3 \mathrm{n} 3$, which are not synthetized by ruminant tissue, and their concentration is dependent on the quantity that flows out to the rumen [5]. These FAs were also detected in cattle hair and result from the direct uptake of FAs from the gut, which are delivered to the organs via blood [14]. A higher content of PUFAs, especially C18:3n3, was reported in milk fat from non-dairy sheep during grazing [6]. This is likely due to the higher concentration of C18:3n3 and C18:2n6c FAs in the pasture. In our study, we determined that the concentration of C18:3n3 was $1.33 \mathrm{mg} / \mathrm{g}$ DM and $0.44 \mathrm{mg} / \mathrm{g}$ DM in July and August, respectively, and the concentration of C18:2n6c was $0.23 \mathrm{mg} / \mathrm{g}$ DM and $0.07 \mathrm{mg} / \mathrm{g}$ DM in July and August (Table 1), respectively, which represent the major FAs found in the pasture.

Significant differences in the wool FA composition were observed according to the classification of ewe milk with high and low milk fat contents for the two time points (30 and 60). The FAs C14:0, C20:3n6, and C24:0 increased in concentration in the early period, as demonstrated by the high milk fat content, but did not exhibit differences when collected at 60 days in the subsequent period. By contrast, the high concentration of the FAs C18:1n9c, $\mathrm{C} 18: 2 \mathrm{n} 6 \mathrm{c}$, and C22:2 was maintained over the two time points (30 and 60 days). In this sense, it is important to note that 30 days represented the point of peak milk yield in ewes [26,29], and, consequently, changes occurred in the pathways involved in FA production. In early lactation, the majority of dairy ruminants are confronted with a negative energy balance, for 
three reasons: the increased demands of calving, decreased dry matter intake shortly before and after calving, and the lagging dry matter intake compared with the energy demands of milk production $[28,30]$. This probably occurred in these animals, as suggested by the marked body weight losses [5]. Thus, long-chain FAs from body fat mobilization would be expected to be incorporated into wool FA, especially C18:1n9c. This can be seen by the higher concentration of long-chain FAs in the wool in this period. Moreover, at 60 days, in contrast to at 30 days, wool from ewes with high milk fat content had a high concentration of de novo synthesized FAs (C10:0 to C16:0). This can be principally explained by the fact that de novo synthesis is reduced when ruminants rapidly mobilize body fat. Wool FAs can originate from four major pathways: directly from the diet, de novo synthesis, formation in the rumen, and released from body fat stores [31]. Among the volatile FAs (VFA), acetate (60-70\% of all VFAs) and the butyrate-derived $\beta$-hydroxybutyrate (BHBA) are the main precursors for the de novo synthesis of FAs in peripheral tissues (70-80\% of acetyl groups for lipogenesis in adipose tissue, 15-30\% in intramuscular depots, and the principal precursor in the mammary gland of the synthesis de novo of FAs) [25]. De novo is the pathway for the C4:0 to C14:0 acids, together with about half of the C16:0 from acetate and BHBA. The other half of the C16:0 acid is partly derived from plasma, from dietary lipids, and from the lipolysis of adipose tissue triacylglycerols, such as FAs with chain lengths of 18 or more carbon atoms [27,32]. In cows, low FA concentrations, in a range from C4:0 to C14:0, were reported in the period of early lactation, compared with the mid-lactation period, due to inhibition of de novo synthesis by long-chain FAs from body fat mobilization [32,33]. Only in periods characterized by a positive energy balance, when an excess of energy and acetyl-CoA are present, can malonyl-CoA be synthetized and de novo FA synthesis be performed, which can be detected throughout the body, including the hair [15]. However, high concentrations of C18:1n9c and other preformed FAs (C18:2n6c and C22:2) are maintained until 60 days in wool from ewes with high fat milk. Kay et al. [34] reported that the preformed FA concentration, originating from adipose tissue mobilization, varied in early lactation, and remained constant through until week 16. The FAs C18:0 and C18:1n9c primarily account for this response in the wool.

In this study, desaturase indexes (DI C14, DI C16, and DI C18) varied according to the classification period and milk fat content. Stearoyl-CoA desaturase (SCD) is the enzyme responsible for the conversion of $\mathrm{C} 14: 1, \mathrm{C} 16: 1$, and $\mathrm{C} 18: 1$, which are produced from $\mathrm{C} 14: 0$, C16:0, and C18:0, respectively [35]. Significant differences were only observed at 30 days in milk in wool fat $(p<0.05)$ with a high DI C14 value in ewes' milk with low fat contents, as compared to milk ewes with high fat contents. Moreover, high values of DI C18 were found in wool from ewes with a high milk fat content $(p<0.05)$. The authors consider that the DI results are related to the activity of the desaturase enzyme. In this sense, DI is probably altered due to the mobilization of reserves and the inhibition of lipogenic enzymes, such as SCD, which occur in animals with a negative energy balance [34]. The lipid composition is affected by the release of non-esterified FA (NEFA), C16:0, C18:0, and, particularly, C18:1n9c. Thus, a major release of $\mathrm{C} 18: 1 \mathrm{n} 9 \mathrm{c}$, together with a further possible conversion of C18:0 to C18:1n9c through the enzymatic activity of SCD [28], can explain the high DI C18 observed in wool collected at 30 days when the milk fat increased.

As described above, several factors affect the wool FA composition, and the energy status of ewes probably plays an important role. Stress can also affect the FA composition of blood and hair or wool and can inhibit complete de novo FA synthesis [14]. Thus, to establish a relationship between wool FAs and milk fat, we calculated the correlations in milk collected at 30 and 60 days. The FAs C18:1n9c, C18:2n6c, and C22:2 were the FAs that maintained a positive correlation in both periods. Various FAs demonstrated different correlations in each period or were not correlated with milk fat content. In the case of C18:1n9c, the current study showed a high concentration of C18:1n9c in wool when the milk fat content increased and a positive correlation with the milk fat variable. Another study determined that, in milk fat, $\mathrm{C} 18: 1 \mathrm{n} 9 \mathrm{c}$ is a useful diagnosis and early warning marker for cows suffering from a severe negative energy balance, but the positive 
correlation shown by $\mathrm{C} 18: 1 \mathrm{n} 9 \mathrm{c}$ between blood NEFA concentration and milk C18:1n9c was only modest $\left(R^{2}=0.383\right)$ [28]. However, we determined a strong positive correlation between $\mathrm{C} 18: 1 \mathrm{n} 9 \mathrm{c}$ and milk fat content (Table 3). Furthermore, the FAs C18:2n6c and C22:2 exhibited the same trend as $\mathrm{C} 18: 1 \mathrm{n} 9 \mathrm{c}$, i.e., increasing when the milk fat was high and with a positive correlation in both periods. C18:1n9c, C18:2n6c, and C22:2 exhibited a greater stability in the classification according to milk fat content variable and presented a positive correlation in both periods. Our focus was to evaluate the concentration of FAs in wool in the discriminant analysis, to determine FAs that represent candidate positive markers of high milk fat concentration. Discriminant analysis of the concentrations of the FAs C18:1n9c, C18:2n6c, and C22:2 in wool fat, used to classify ewes with high milk fat contents, demonstrated an accuracy of $79.17 \%$ with the FA C18:1n9c, and a maximum of accuracy of $87.50 \%$ when the FA C18:2n6c was included.

As mentioned above, the FA C18:1n9c is released from body reserves and is a product of SCD activity, thus, it reflects the mobilization of body fat. However, the other preformed FAs of interest, i.e., C18:2n6c and C22:2, originate from the diet and are not synthetized by ruminant tissue. Considering the origin of the FAs, it is difficult to consider C18:2n6c and $\mathrm{C} 22: 2$ as candidates with which to discriminate milk fat content, because their concentration in wool fat depends on diet. Thus, we suggest analyzing these FAs in different production systems and diets, because this function was evaluated in the conditions of the present study. The authors consider $\mathrm{C} 18: 1 \mathrm{n} 9 \mathrm{c}$ concentration in wool fat in the period of the current study to be a positive marker for milk fat content. Although milk fat content can be directly determined, the utilization of wool FAs as markers of milk fat can also be used to determine ewe status during lactation and be decisive in matters of nutritional supplementation during this period. Moreover, the FA C18:1n9c in wool fat may be conveniently included in routine analyses when testing milk FAs.

\section{Conclusions}

This study is the first to report the potential utilization of wool FAs for determining ewe milk fat content in two periods of lactation, based on correlation. According to the discriminant analysis, ewes with a high milk fat content could be identified based on the concentration of the FAs C18:1n9c and C18:2n6c in the wool, with an accuracy of $87.50 \%$, under the conditions in which the study was carried out. The utilization of wool integral lipid results is beneficial, due to the information that this provides, being easy to obtain and low cost to store, and it represents a noninvasive method for improving dairy products, whose direct beneficiaries happen to be small dairies and local communities.

Author Contributions: Conceptualization and methodology, K.I.; formal analysis and data curation, G.L.; investigation, M.D.; writing—original draft preparation, S.B. and K.I.; writing—review and editing, N.S. All authors have read and agreed to the published version of the manuscript.

Funding: This study was supported by ANID/CONICYT FONDECYT Initiation Project 11170460.

Institutional Review Board Statement: This study was approved by University of La Frontera Scientific Ethical Committee (ethical review number 101_17).

Informed Consent Statement: Not applicable.

Data Availability Statement: All data obtained in this study are available in the article.

Conflicts of Interest: The authors declare no conflict of interest.

\section{References}

1. Gatzias, I.S.; Karabagias, I.K.; Kontakos, S.P.; Kontominas, M.G.; Badeka, A.V. Characterization and differentiation of sheep's milk from Greek breeds based on physicochemical parameters, fatty acid composition and volatile profile. J. Sci. Food Agric. 2018, 98, 3935-3942. [CrossRef]

2. Nudda, A.; Battacone, G.; Boaventura, O.; Cannas, A.; Francesconi, A.H.D.; Atzori, A.S.; Pulina, G. Feeding strategies to design the fatty acid profile of sheep milk and cheese. Rev. Bras. Zootec. 2014, 43, 445-456. [CrossRef] 
3. Balthazar, C.F.; Pimentel, T.C.; Ferrão, L.L.; Almada, C.N.; Santillo, A.; Albenzio, M.; Mollakhalili, N.; Mortazavian, A.M.; Nascimento, J.S.; Silva, M.C.; et al. Sheep Milk: Physicochemical Characteristics and Relevance for Functional Food Development. Compr. Rev. Food Sci. Food Saf. 2017, 16, 247-262. [CrossRef]

4. Aguilar, C.; Toro-Mujica, P.; Vargas-Bello-Pérez, E.; Vera, R.; Ugalde, C.; Rodríguez, S.; Briones, I. A comparative study of the fatty acid profiles in commercial sheep cheeses. Grasas Aceites 2014, 65, e048. [CrossRef]

5. Addis, M.; Cabiddu, A.; Pinna, G.; Decandia, M.; Piredda, G.; Pirisi, A.; Molle, G. Milk and cheese fatty acid composition in sheep fed Mediterranean forages with reference to conjugated linoleic acid cis-9,trans-11. J. Dairy Sci. 2005, 88, 3443-3454. [CrossRef]

6. Rozbicka-Wieczorek, A.J.; Radzik-Rant, A.; Rant, W.; Kuczyńska, B.; Czauderna, M. Characterization of the milk lipid fraction in non-dairy sheep breeds. Arch. Anim. Breed. 2015, 58, 395-401. [CrossRef]

7. Park, Y.W.; Juárez, M.; Ramos, M.; Haenlein, G.F.W. Physico-chemical characteristics of goat and sheep milk. Small Rumin. Res. 2007, 68, 88-113. [CrossRef]

8. Bencini, R.; Pulina, G. The quality of sheep milk: A review. Aust. J. Exp. Agric. 1997, 37, 485. [CrossRef]

9. Lešić, T.; Pleadin, J.; Krešić, G.; Vahčić, N.; Markov, K.; Vrdoljak, M.; Frece, J. Chemical and fatty acid composition of cow and sheep milk cheeses in a lamb skin sack. J. Food Compos. Anal. 2016, 46, 70-77. [CrossRef]

10. Pulina, G.; Nudda, A.; Battacone, G.; Cannas, A. Effects of nutrition on the contents of fat, protein, somatic cells, aromatic compounds, and undesirable substances in sheep milk. Anim. Feed Sci. Technol. 2006, 131, 255-291. [CrossRef]

11. Martin, M.; Herlaar, S. Environmental and social performance of valorizing waste wool for sweater production. Sustain. Prod. Consum. 2021, 25, 425-438. [CrossRef]

12. Monahan, F.J.; Moloney, A.P.; Osorio, M.T.; Röhrle, F.T.; Schmidt, O.; Brennan, L. Authentication of grass-fed beef using bovine muscle, hair or urine. Trends Food Sci. Technol. 2012, 28, 69-76. [CrossRef]

13. Jia, J.-Y.; Zhang, L.-N.; Lu, Y.-L.; Zhang, M.-Q.; Liu, G.-Y.; Liu, Y.-M.; Lu, C.; Li, S.-J.; Lu, Y.; Zhang, R.-W.; et al. Hair analysis, a reliable and non-invasive method to evaluate the contamination by clenbuterol. Ecotoxicol. Environ. Saf. 2013, 93, 186-190. [CrossRef]

14. Moeller, R.; Nuernberg, K.; Schmitt, A.O.; Brockmann, G.A. Relationship between hair fatty acid profile, reproduction, and milk performance in Holstein Friesian cows. J. Anim. Sci. 2013, 91, 1669-1676. [CrossRef]

15. Möller, R.; Dannenberger, D.; Nürnberg, G.; Strucken, E.-M.; Brockmann, G.A. Relationship between the fatty acid profile of hair and energy availability of lactating primiparous cows. J. Dairy Res. 2019, 86, 77-84. [CrossRef] [PubMed]

16. Russel, A. Body condition scoring of sheep. Pract 1984, 6, 91-93. [CrossRef] [PubMed]

17. Canseco, C.; Demanet, R.; Balocchi, O.; Parga, J.; Anwandter, V.; Abarzúa, A.; Teuber, N.; Lopetegui, J. Determinación de la disponibilidad de materia seca de praderas en pastoreo. In Manejo del Pastoreo; Imprenta América: Osorno, Chile, 2007; Volume I, pp. 23-50.

18. Burja, A.M.; Armenta, R.E.; Radianingtyas, H.; Barrow, C.J. Evaluation of Fatty Acid Extraction Methods for Thraustochytrium sp. ONC-T18. J. Agric. Food Chem. 2007, 55, 4795-4801. [CrossRef] [PubMed]

19. Folch, J.; Lees, M.; Stanley, G.S. A simple method for the isolation and purification of total lipides from animal tissues. J. Biol. Chem. 1957, 226, 497-509. [CrossRef]

20. Fuertes, J.A.; Gonzalo, C.; Carriedo, J.A.; San Primitivo, F. Parameters of test day milk yield and milk components for dairy ewes. J. Dairy Sci. 1998, 81, 1300-1307. [CrossRef]

21. ISO. IDF-Milk and Milk Products-Guidelines for the Application of Mid-Infrared Spectrometry (ISO: 9622-2013); 2nd ed. International Organization for Standarization: Geneva, Switzerland, 2013.

22. Coderch, L.; de la Maza, A.; Soriano, C.; Erra, P.; Parra, J.L. Chromatographic characterization of internal polar lipids from wool. J. Am. Oil Chem. Soc. 1995, 72, 715-720. [CrossRef]

23. Seabold, S.; Perktold, J. Statsmodels: Econometric and Statistical Modeling with Python. In Proceedings of the 9th Python in Science Conference, Austin, TX, USA, 28 June 2010.

24. Körner, A.; Höcker, H.; Rivett, D.E. The fatty acid composition of lipids from the wool cell membrane complex. Fresenius J. Anal. Chem. 1992, 344, 501-509. [CrossRef]

25. Bionaz, M.; Vargas-Bello-Pérez, E.; Busato, S. Advances in fatty acids nutrition in dairy cows: From gut to cells and effects on performance. J. Anim. Sci. Biotechnol. 2020, 11, 110. [CrossRef]

26. Inostroza, K.; Bravo, S.; Larama, G.; Saenz, C.; Sepúlveda, N. Variation in Milk Composition and Fatty Acid Profile during the Lactation of Araucana Creole Ewes in a Pasture-Based System. Animals 2020, 10, 92. [CrossRef] [PubMed]

27. Månsson, H.L. Fatty acids in bovine milk fat. Food Nutr. Res. 2008, 52, 1821. [CrossRef] [PubMed]

28. Jorjong, S.; van Knegsel, A.T.M.; Verwaeren, J.; Lahoz, M.V.; Bruckmaier, R.M.; De Baets, B.; Kemp, B.; Fievez, V. Milk fatty acids as possible biomarkers to early diagnose elevated concentrations of blood plasma nonesterified fatty acids in dairy cows. J. Dairy Sci. 2014, 97, 7054-7064. [CrossRef]

29. Pollott, G.E.; Gootwine, E. Reproductive performance and milk production of Assaf sheep in an intensive management system. J. Dairy Sci. 2004, 87, 3690-3703. [CrossRef]

30. Ospina, P.A.; Nydam, D.V.; Stokol, T.; Overton, T.R. Evaluation of nonesterified fatty acids and beta-hydroxybutyrate in transition dairy cattle in the northeastern United States: Critical thresholds for prediction of clinical diseases. J. Dairy Sci. 2010, 93, 546-554 [CrossRef] 
31. Stoop, W.M.; Bovenhuis, H.; Heck, J.M.L.; van Arendonk, J.A.M. Effect of lactation stage and energy status on milk fat composition of Holstein-Friesian cows. J. Dairy Sci. 2009, 92, 1469-1478. [CrossRef] [PubMed]

32. Garnsworthy, P.C.; Masson, L.L.; Lock, A.L.; Mottram, T.T. Variation of Milk Citrate with Stage of Lactation and De Novo Fatty Acid Synthesis in Dairy Cows. J. Dairy Sci. 2006, 89, 1604-1612. [CrossRef]

33. Palmquist, D.L.; Beaulieu, A.D.; Barbano, D.M. Feed and Animal Factors Influencing Milk Fat Composition. J. Dairy Sci. 1993, 76, 1753-1771. [CrossRef]

34. Kay, J.K.; Weber, W.J.; Moore, C.E.; Bauman, D.E.; Hansen, L.B.; Chester-Jones, H.; Crooker, B.A.; Baumgard, L.H. Effects of week of lactation and genetic selection for milk yield on milk fatty acid composition in Holstein cows. J. Dairy Sci. 2005, 88, 3886-3893. [CrossRef]

35. Cabiddu, A.; Decandia, M.; Addis, M.; Piredda, G.; Pirisi, A.; Molle, G. Managing Mediterranean pastures in order to enhance the level of beneficial fatty acids in sheep milk. Small Rumin. Res. 2005, 59, 169-180. [CrossRef] 